DOI: 10.17234/SRAZ.65.29

\title{
Nomadismo literário e escrita extraterritorial: o caso Jorge Listopad
}

\author{
Yana Andreeva \\ Universidade de Sófia Sveti Kliment Ohridski, \\ Faculdade de Filologias Clássicas e Modernas, Bulgária \\ jandreeva@uni-sofia.bg
}

A comunicação propõe-se analisar a construção da representação do escritor nómada nas narrativas autobiográficas do escritor português de origem checa Jorge Listopad, nomeadamente nas narrativas das coletâneas Biografia de Cristal (1992), Deslizamento (2009) e Remington (2013). O estudo concentra-se na focagem das caraterísticas da escrita extraterritorial de Listopad, sendo destacada a recorrência temática das questões vinculadas à migração e ao nomadismo.

Palavras-chave: Jorge Listopad, escrita nómada, extraterritorialidade, migração, literatura autobiográfica

Em 1968, George Steiner dá, no seu livro Extraterritorial: a literatura e a revolução da linguagem, a primeira definição, em termos cronológicos, de uma categoria muito especial entre os escritores, que hoje em dia, na época das migrações globais mais intensas, diríamos ser cada vez mais recorrente: a do escritor extraterritorial. Trata-se, nas palavras de Steiner, de "um escritor linguisticamente desabrigado, de um poeta, romancista, dramaturgo não completamente em casa na língua de sua produção, mas deslocado ou em hesitação na fronteira" (Steiner 1990: 15).

O escritor Jorge Listopad (1921-2017), que apesar de ser de origem checa obtém a sua consagração literária em Portugal, é precisamente um escritor extraterritorial. As suas obras caraterizam-se invariavelmente por aqueles traços da escrita extraterritorial que Steiner formula no seu estudo, dedicado a Nabokov (e que aqui passo a referir muito resumidamente): o bilinguismo, que em alguns casos é até plurilinguismo; a pressão ativa que uma ou mais línguas diferentes exercem sobre a língua em que se escreve e que se manifesta na tradução "interna" de modos de sentir e de se expressar alheios; a estruturação binária do sistema de valores, colocando a ênfase em tendências que às vezes se apresentam como contrárias, resultando daí a enigmática coexistência de mundividências várias, originadas na linguagem e simultaneamente a dar origem à linguagem; a consciência explícita de se estar entre duas línguas e a possível existência de uma língua mista, o que permite a experimentação estilística com a linguagem 
por meio da introdução de locuções e recursos dessa língua mista, que não raro funciona como criptolíngua autoral específica (ver Steiner 1990: 15-21). Os textos de cariz autobiográfico de Listopad não só ilustram no seu tecido discursivo esta imbricação do linguístico e do cultural quando referidos à problemática da desterritorialização do indivíduo migrante, mas também tematizam abertamente todas essas questões, construindo uma representação abrangente do indivíduo que escreve noutra língua e noutro lugar, alheios mesmo quando se tenta tornálos próprios por meio de uma admirável perseverança da escrita.

Para compreender a presença destes traços da escrita extraterritorial e os sentidos da sua tematização nos textos de Jorge Listopad faz-se necessário abordar a questão das problemáticas da migração e do nomadismo, muito recorrentes na obra do escritor. Tematicamente vinculados à questão da escrita extraterritorial, tal como a concebe o próprio autor, os tópicos da migração e do nomadismo impõem-se como assuntos de primeira importância na narrativa ficcional de Listopad. Nesta aproximação às dimensões cada vez mais evidentes que a extraterritorialidade vai adquirindo ao longo da produção literária do escritor, não devemos esquecer que se trata de um intelectual da Europa de Leste que viveu a experiência da clandestinidade, da fuga e do exílio. Afigura-se-nos portanto natural que a sua prosa literária, em que o passado de foragido, exilado e migrante é repetidamente ficcionalizado, contenha um projeto de construção da representação global da migração, balizado no traçado dos múltiplos aspetos histórico-sociais, culturais, psicológicos e linguísticos que à migração se associam.

Para analisar a projeção dos fenómenos imbricados da extraterritorialidade e da migração na construção de sentido na ficção em prosa de Jorge Listopad tratarei em detalhes a representação da extraterritorialidade literária do escritor nómada. Aqui falarei de Remington (2013), a última coletânea de contos publicada por Listopad em vida, e de mais duas coletâneas anteriores que incluem narrativas breves e fragmentos introspetivos: uma é Biografia de Cristal, de 1992, que cronologicamente é a primeira coletânea de narrativas, editada por Listopad (posteriormente será integrada no volume II de O Jardim Fecha às 18:30. Prosa Reunida, de 2004), a outra é Deslizamento, de 2009. É de notar o denominador comum das três coletâneas: todas elas contêm textos de caráter marcadamente autobiográfico que tematizam a migração, extraindo da reflexão sobre as circunstâncias e a essência da migração o sentido profundo da vida de um sujeito que se autodefine como criador nómada e que, sentindo-se desterritorializado pelo seu destino de migrante, procura a escrita como forma de reterritorializar a sua existência individual.

Biografia de Cristal (1992) anuncia as tónicas temáticas fundamentais na prosa de ficção de Listopad. Os fragmentos, enunciados numa primeira pessoa autobiográfica, podem ser agrupados em vários conjuntos: 1) fragmentos autobiográficos referenciais, que reproduzem a memória do passado do sujeito narrador; 2) microficções alegórico-fantásticas, que tematizam a solidão, a transgressão, a traição, a fuga, a destruição, a perseguição, a travessia, a salvação; 3) fragmentos intimistas de marcado teor lírico; 4) fragmentos de índole metanarrativa, que descrevem os processos e a intencionalidade da escrita criativa, veiculando a reflexão sobre os seus mecanismos e resultados. 
Os tópicos da migração como desterritorialização, errância e nomadismo, que encontramos já desenvolvidos tematicamente nesta espécie de autobiografia ficcionalizada que é Biografia de Cristal, serão retomados em Deslizamento (2009) e Remington (2013) que são, de certa maneira, a reescrita das memórias do escritor nómada, com o acréscimo de novas personagens, episódios e interpretações. Deslizamento (2009) merece sem dúvida uma atenção especial por acrescentar novas e valiosas perspetivas ao tratamento do tema da migração, na compilação de fragmentos declaradamente autobiográficos de "Silva Rerum", que aparece como última, quinta parte da coletânea. "Silva Rerum" narra episódios da infância passada em Praga, traça a história familiar, refere num registo memorialista o convívio com a elite intelectual de Paris nos anos da emigração francesa, com a do Porto após a chegada a Portugal, chegando a registar também acontecimentos mais recentes na vida do escritor. Remington (2013), finalmente, reúne nos seus 48 contos histórias ficcionais e autobiográficas, entre cujas personagens encontramos migrantes de todas as idades e de origem diversa, alguns deles nómadas, outros já sedentários. A "melancolia eslava" (Listopad 2013: 5), que carateriza estas últimas narrativas e algumas das suas personagens, define também a tonalidade emotiva que preside o tratamento dos motivos autobiográficos em que se recriam a juventude do sujeito e o seu destino de emigrante.

Vejamos a seguir mais pormenorizadamente os elementos dessa representação da migração que a prosa autobiográfica de Jorge Listopad constrói de uma forma sistemática e redundante ao longo de várias décadas. Fazemos notar desde já que essa sistematicidade e redundância com que é abordado o complexo temático da migração, se por um lado contradiz a forma fragmentária e a descontinuidade elíptica dos breves textos que compõem a prosa de Listopad, por outro, vêm a afirmar de forma marcada e insistente a essencial descontinuidade que a migração e o nomadismo implicam em si.

Logo no seu início Biografia de Cristal situa o sujeito fora da sua pátria, i.e. fora dos limites territoriais do seu lugar natal, num espaço alheio que, mesmo que escolhido como porto seguro pelo sujeito, mesmo que olhado com "óculos amigos" (Listopad 2004: 110), não deixa de ser uma terra "alheia", que se parece com todas as terras alheias do mundo: "Das terras alheias, a melhor é Linda-aVelha. [...] Portugal é Linda-a-Velha." (ibidem: 95-96).

A consciência de cisão do sujeito, dividido entre o próprio e o alheio, espelhase na impossibilidade de se fixar no espaço e na decorrente sensação da sua indefinição espacial, que se expressa tanto por motivo das frequentes viagens por Portugal e pelo mundo, encaradas como circunstâncias profissionais forçadas, ou inevitável sina, como nas intermináveis e cansativas deslocações da casa em Linda-a-Velha, que é sua residência fixa, ao estúdio alugado na Graça e depois, novamente, no sentido contrário: "Subo, desço, desço, subo, Graça, Linda-a-Velha, fujo de um sítio para o outro..." (ibidem: 97). Tal indefinição no espaço, aliada à impossibilidade de suspender o extenuante percurso e de conseguir assim uma fixação redentora, pode ser lida, a nível do sentido global do arquitexto de Listopad, como transposição metafórica do estigma do exílio motivado pelas 
origens judaicas, que desde a infância marca o protagonista com o selo do nómada que é o da não-pertença a lugar nenhum.

Perseguido e expulso do país natal e por isso marcado para toda a vida com o trauma do exílio, o sujeito autobiográfico na prosa de Listopad não esconde a alienação em relação a todos os espaços que atravessa na longa peregrinação em que vai acumulando o seu capital de migrante. Os motivos migratórios conjugamse, penetrados por uma melancolia apaziguada pelos anos, melancolia em que falta aquela dimensão de sofrimento que Edward Said chama de "páthos do exílio" e que se identifica com "a perda de contato com a solidez da terra: voltar para o lar está fora de questão" (2003: 52).

Para o sujeito autobiográfico que protagoniza as narrativas curtas de Listopad, o nomadismo representa uma opção própria, uma escolha consciente. Tal escolha é reiterada numa série de decisões consecutivas de fuga, mudança, retirada, deslocação, procura de um novo lugar, busca de um rumo existencial ou profissional diferente. A partir da renúncia à sua primeira pátria, que chama "minha velha pátria" ou "minha ex-pátria" (Listopad 2013: 42), o autobiógrafo assume a sua natureza intrínseca de nómada, peregrino, vagamundo, ser errante. O texto que trata da forma mais explícita e concentrada o tema da errância do migrante, para formular a tese do seu inevitável nomadismo, é o conto "Estrangeiro procura o estrangeiro" da coletânea Remington. Anunciando no seu início, como sábia revelação, que "nada é definitivo, que o real é provisório" (ibidem: 33), o narrador protagonista relata a história das suas andanças por terras diversas, traçando com precisão e minúcia o roteiro da peregrinação: de Paris para Temesvár, na Panónia; de Temesvár para a ilha da Jutlândia, na Dinamarca; de Jutlândia a Boston, na América do Norte. A paisagem humana, desenhada a grossas pinceladas, é composta sobretudo por migrantes. Em Paris, são os "homens das mudanças, esses proletários sem classe, sempre estrangeiros no sítio onde trabalham, que de manhã bebem, com o café, um copo de rakia da sua terra e almoçam cerveja com um pedaço de carne e pão do dia anterior, sempre a mesma ementa" (ibidem: 34). Em Temesvár, são o "eslovaco errático" e os "poetas que escrevem seine Dichtung em alemão e depois mudam de nome e de língua, e escrevem em sérvio como quem faz uma experiência, ao que me foi dito, e se não me engano com um terceiro nome redigem também em húngaro" (idem). Em Boston, as imagens retratadas são as dos linguistas canadianos e russos, alguns dos quais, como Roman Jakobson, passaram também por Praga (ibidem: 36).

No prosseguir do seu trajeto, o migrante pouco a pouco se vai libertando dos pesos que outrora o atavam à vida sedentária, libertando-se também do sentimento de pertença. Os lugares que habita também vão perdendo pouco a pouco a sua solidez material, vão se tornando mais simples e descomplicados, impondo-se cada vez de forma mais intensa a sensação de se estar desvinculando de tudo e de todos, de se ver livre de qualquer envolvimento com o espaço circundante. $O$ apartamento bem mobilado de Paris é substituído por um pequeno mas confortável refúgio na cidade panónica, ao que se segue o albergue e depois um simples iate. Ancorado "numa marina das águas do mar do Norte", esse barco "que tinha em baixo um lugar para se dormir, comer e amar" (ibidem: 
35) constitui-se como a metáfora do lugar de passagem, provisório, incerto e sempre em movimento, como as águas flutuantes que o cercam. A vida em Boston, em contrapartida, trará ao protagonista a tentação do sedentarismo. Será aí que o imigrante, que já experimentou diversas ocupações profissionais, tornará a praticar os afazeres do intelectual, inscrevendo-se na universidade e convivendo com os seus professores, também imigrantes como ele. A ilusão de estar vinculado ao lugar que se habita parece chegar a um grau máximo de completude quando o protagonista se decide a tentar um grau de docência e a casar com Marie. Confrontado com a falta de harmonia no seu matrimónio e com as promessas de felicidade que não se cumprem na vida sedentária, o nómada de outrora reconquista o seu nomadismo visceral, ao chegar àquela certeza final que repete especularmente a afirmação com que abre a narrativa. Assim, a frase inicial do conto "Tinha de me mudar, pacificamente" (Listopad 2013: 33) reflete-se na asserção final "Compreendi que tinha chegado o tempo de mudar" (ibidem: 36). Nesse passo conclusivo parecem ressoar as palavras de um dos exilados mais conhecidos da nossa contemporaneidade, o antes citado Edward Said, cujas reflexões sobre o exílio também são o resultado de uma vivência existencial: “O exílio é a vida levada fora da ordem habitual. É nómada, descentrada, contrapontística, mas, assim que nos acostumamos a ela, sua força desestabilizadora entra em erupção novamente" (2003: 60).

O final do conto apresenta-se como um comentário metatextual que iguala a vida do nómada à sua escrita também errante, confirmando de forma definitiva a consciência de nómada que o sujeito autobiográfico tem de si, ao se conceber como um eterno estrangeiro que transita no espaço entre diferentes lugares de acolhimento sem nunca se ligar a eles. Esse protagonista que se autodefine como um estrangeiro já está tão habituado ao estranhamento, que continua a procurar o estranho tenazmente, e cada vez com mais afinco, pois percebe que é desta falta de fixidez que lhe nasce a dinâmica do destino, e que desse destino lhe nasce a obra. Uma obra cujos títulos, anunciados em progressão, como opções consecutivas, também incertos e sujeitos à mudança, sintetizam metaforicamente os múltiplos significados do nomadismo como errância eterna e sem rumo certo do homem à procura da felicidade. E é justamente com a citação deste trecho final do conto "Estrangeiro procura o estrangeiro" de Remington que poderia terminar esta aproximação à escrita nómada de Jorge Listopad:

Agora para onde vou? Escrevi um livro, Seguro nas Águas, mas deixei-o algures na Dinamarca; porém resolvi agora aproveitar o que era o seu lado poético e transformá-lo num texto intitulado: Estrangeiro procura o estrangeiro. Ainda só tenho algumas dezenas de páginas redigidas e o que aqui escrevo faz parte da síntese desse futuro romance, de certo modo autobiográfico.

Ao ler este texto lembrei-me de que vivi em Paris, em Temesvár, na ilha da Jutlândia e por fim em Boston, na América do Norte, tão perto, tão perto do Canadá, e que estou a escrever este grande romance sem saber para onde vou, sem saber porque vou à procura de uma terra firme que me não fuja por baixo das solas cansadas. (Listopad 2013: 36). 
Assim, a consciência nómada que se afirma nos textos de Listopad é a da transitoriedade no espaço e de uma temporalidade incerta, a pairar sobre um presente que flui sem sentido definido. O sujeito autobiográfico, nómada descentrado, deslocado na sua identidade, ora se encontra no lugar da língua, ora se percebe fora dela, podendo revelar o seu instinto de pertença a um lar unicamente através da perseverança na escrita. É o que invariavelmente nos mostram todos os textos de Jorge Listopad na sua tenaz problematização da escrita como meio de reterritorializar a existência do escritor nómada, na sua sinceridade poética e na sua incansável ambição de se alcançar a plenitude.

\section{Bibliografia}

Listopad, Jorge (1992). Biografia de Cristal, Lisboa: Relógio d'Água.

Listopad, Jorge (2004). O Jardim Fecha às 18:30. Prosa Reunida, Vol. II, Vila Nova de Famalicão: Ed. Quasi.

Listopad, Jorge (2009). Deslizamento, Matosinhos: QuidNovi.

Listopad, Jorge (2013). Remington, Lisboa: Cavalo de Ferro Editores.

Said, Edward W. (2003). Reflexões sobre o exílio e outros ensaios [trad. Pedro Maia Soares], São Paulo: Companhia das Letras.

Steiner, George (1990). Extraterritorial: a literatura e a revolução da linguagem [trad. Júlio Castañon Guimarães], São Paulo: Companhia das Letras.

\section{Literary nomadism and extraterritorial writing: the case of Jorge Listopad}

The paper focuses on the representation of nomadic writing in the autobiographical narratives of the Portuguese writer of Czech origin Jorge Listopad in the collections of short stories Biografia de Cristal (1992), Deslizamento (2009) and Remington (2013).

The study focuses on the characteristics of Listopad's extraterritorial writing, highlighting the thematic recurrence of issues related to migration and nomadism.

Key words: Jorge Listopad, nomadic writing, extraterritoriality, migration, autobiographical literature 